\title{
PECULIARITIES OF DEWATERING TECHNOLOGY FOR HEAVY HIGH-VISCOSITY CRUDE OILS OF EASTERN REGION OF UKRAINE
}

\author{
Petro Topilnytskyy ${ }^{1,}{ }^{\otimes}$, Tetiana Yarmola ${ }^{1}$,Viktoria Romanchuk ${ }^{1}$, \\ Justyna Kucinska-Lipka ${ }^{2}$
}

https://doi.org/10.23939/chcht15.03.423

\begin{abstract}
High-viscosity crude oils from the Yablunivske field (Ukraine, Poltava region) have been studied. The oils were diluted with gas condensate to reduce viscosity, and then various demulsifiers were added. It was established that it is expedient to dilute oil with heavy gas condensate and dehydrate it with PM-1441 brand A non-ionogenic demulsifier, based on block copolymers of ethylene and propylene oxides. The dewatering degree was found to be $95 \%$.
\end{abstract}

Keywords: heavy oil, dewatering, demulsification, demulsifier.

\section{Introduction}

The share of hard-to-extract reserves in the structure of hydrocarbon reserves is constantly increasing; their development in modern economic conditions is associated with significant investments. Today, more than 80 million barrels of crude oil per day is produced in the world, about 11 million barrels of which are classified as heavy oil [1]. The two largest fields in the world are the Orinoco Belt heavy oil field in western Venezuela and the bituminous sands on the eastern slope of the western Canadian basin, with total oil reserves of 3,600 billion barrels in the reservoir. For comparison, the current world reserves of traditional oil are 952 billion barrels of oil, according to the US Geological Survey [2].

In Ukraine, over last 30 years the volume of such reserves increases by almost three times and has exceeded $68 \%$ of total reserves. These are, first of all, oil reserves in low-permeability reservoirs, residual hydrocarbon reserves, which are formed at the late stage of field development, highly waterlogged deposits, heavy highviscosity oil and bitumen [3].

\footnotetext{
${ }^{1}$ Lviv Polytechnic National University

12, S.Bandery St., 79013 Lviv, Ukraine

${ }^{2}$ Gdansk University of Technology,

11/12 G.Narutowicza St., Gdansk80-233, Poland

petro.i.topilnytskyi@lpnu.ua

C Topilnytskyi P., Romanchuk V., Yarmola T., Kucinska-Lipka J., 2021
}

According to the literature, the density of heavy and bituminous oil is $870-895 \mathrm{~kg} / \mathrm{m}^{3}$ and $>895 \mathrm{~kg} / \mathrm{m}^{3}$, respectively. Such oils are characterized by a high content of aromatic hydrocarbons, concentration of metals and sulfur-containing compounds, as well as high coking ability. The high viscosity of oils is caused by the high content of resin-asphaltene components (RAC) $[4,5]$. When the critical concentration of RAC in oil is reached, there is a sharp change in rheological properties, whereas structural and mechanical properties begin to manifest themselves to a large extent. The reason is intermolecular interactions of RAC with other molecules of the oil dispersed system. RAC affects the stabilization of the oil emulsion and increases its viscosity [6].

High-viscosity oils are characterized by high production costs, virtually impossible transportation by existing oil pipelines and unprofitable refining according to classical schemes.

It is assumed that the decrease in the viscosity of oils and petroleum products is achieved by dispersing asphaltenes when dispersant (toluene, xylenes, furan, etc.) is introduced into the oil in the amount of $0.1-25 \mathrm{wt} \%$, which leads to a decrease in viscosity and aggregative stability of the oil dispersion system. In addition to the high content of RAC, high-viscosity oils can be characterized by the low content of light fractions, which also leads to the increased density and viscosity. The main requirements for the oil diluent are: affinity (lyophilicity) to the resin-asphaltene part of the raw material to ensure the stability of the colloidal medium; heat resistance in the specified working range time and temperature; being in the liquid phase under operating conditions and ensuring the maximum effect of dissolution [7-9].

In addition to problems with the extraction and transportation of heavy oil, there are problems of its processing due to the complexity of its preparation, namely dewatering and desalting [10]. The complete process of dewatering is hindered by the high content of mechanical impurities and stabilizers in the hydrocarbon feedstock. This indicator is important both in terms of preparation and further refining of oil, because mechanical 
impurities cause abrasive wear of pipelines, process equipment and the formation of stable emulsions. Moreover, the high content of water and chloride salts in the oil causes severe corrosion of process equipment, increased energy consumption and reduced maintenance of installations [11]. In the process of oil dewatering, particles of mechanical impurities settle together with large drops of water at the phase boundary, forming concentrated intermediate layers, thereby deteriorating the preparation of oil $[12,13]$.

Various methods are used for desalting and dewatering of heavy viscous oils [14-16].

Demulsification methods can be divided into five types: chemical demulsification (application of chemical reagents), physical demulsification (centrifugation, gravitational sedimentation, membrane demulsification and vibration demulsification), biological demulsification and combined methods [17-20]. A relatively new method is the application of membrane technology for dewatering. Wu et al. [21] investigated the effect of membrane surface charges on the crude oil demulsification and resistance to contamination. The mechanism of demulsification by the membrane-surfactant interaction was investigated. But in the case of high-viscosity oils, this method is ineffective.

The combination of demulsification by ultrasound and chemical methods increases the effect of dewatering, especially in the case of heavy oils [22-25]. However, the use of only physical methods, especially in the case of dewatering of heavy oil, without the use of special reagents is ineffective.

The use of special reagents - demulsifiers - has become widespread for the oil dewatering. Various substances can be used as demulsifiers: cationic, anionic and non-ionogenic surfactants [26]. Studies of heavy oils dewatering were carried out using as demulsifiers the ionogenic liquids, which usually consist of organic cations and inorganic or organic anions [27-28]. Flores et al. [29] used ionogenic liquids such as trioctylmethylammonium and ammonium salt for extra-heavy crude oil demulsification and achieved dewatering degree of $95 \%$.

An investigation of a composite demulsifier based on an oligourethane-type reagent with $10 \%$ addition of zwitter ionogenic surfactants is described in [30]. A new multifunctional composite demulsifier STHDP-11M was developed. The results of laboratory and experimentalindustrial tests showed good dynamics of water settling in comparison with basic reagents due to the synergistic action of the components included in the STHDP-11M composition. Al-Sabagh et al. [31] studied the demulsifying activity of poly(maleic anhydride-alt-1dodecene) modified with polyethylene glycol (PEG 1000) and polypropylene glycol (PPG 1000). The obtained results showed that the molecular structure of the prepared demulsifiers directly affects the demulsification process. Demulsifiers with a higher content of ethylene oxidepropylene oxide had higher demulsification efficiency.

The most common today are non-ionogenic demulsifiers, i.e. they do not dissociate into ions in aqueous solutions. Usually, demulsifiers of this type are prepared by the addition of ethylene oxide or propylene oxide to organic substances containing a mobile hydrogen atom. Organic acids, alcohols, phenols, etc., as well as ethylene oxide and propylene oxide, can serve as initial raw materials for such synthesis.

Non-ionogenic surfactants are currently the most widely used in the processes of dewatering and desalting of oil due to a number of advantages over ionogenic ones. The high efficiency of demulsification using a high molecular non-ionogenic surfactant is described in [3234]. Adilbekova et al. [35] found that non-ionogenic demulsifier made of polyethyleneamine with different content of ethylene oxide and propylene showed the best results on dewatering when the emulsion temperature rises to $323 \mathrm{~K}$.

However, only this method is also ineffective for the heavy oils dewatering.

Not only demulsifier is necessary to increase the efficiency of desalting and dewatering of heavy viscous oil [36]. It would be useful to pre-dilute oil and reduce its viscosity with a diluent, such as light low-viscosity oil $(30-70 \mathrm{wt} \%$ relative to the raw material), gasoline distilled from heavy viscous oil, gasoline after thermal refining, trapped gasoline formed on the basis of resulting products, or stable gas condensate $[37,38]$.

The purpose of this work is to dewater (dehydrate) heavy oils from the eastern region of Ukraine, combining dilution and selection of an effective demulsifier and dewatering conditions.

\section{Experimental}

\subsection{Initial Materials}

Oils from 4 wells of the Yablunivske field (Poltava region, Ukraine) were under study. These oils are highviscosity and may contain natural bitumen. The extraction of such oils by traditional methods is inefficient and sometimes virtually impossible because they have properties of non-Newtonian fluid. The samples under study were: sample 1 - well 88 , sample 2 - well 94 , sample 3-well 337, sample 4 - well 153; the samples differed in density, viscosity and pour point.

Physico-chemical parameters of the samples were determined previously by the methods described in [39], their characteristics are represented in Table 1. 
Characteristics of raw materials

\begin{tabular}{|l|c|c|c|c|}
\hline \multicolumn{1}{|c|}{ Index } & Sample 1 & Sample 2 & Sample 3 & Sample 4 \\
\hline Density at 293 K, $\mathrm{kg} / \mathrm{m}^{3}$ & 975 & 985 & 970 & 953 \\
\hline Kinematic viscosity at 313 K, $\mathrm{mm}^{2} / \mathrm{s}$ & 495 & $2100^{*}$ & 475 & $29.2^{* *}$ \\
\hline Coking ability,wt\% & 10.1 & 10.6 & 7.1 & 6.9 \\
\hline Water content, vol\% & 5.0 & 25.0 & 5.5 & 5.5 \\
\hline Chlorides content, $\mathrm{mg} / \mathrm{dm}^{3}$ & 2890 & 5400 & 7351 & 1320 \\
\hline Sulfuric-acidresinscontent, vol\% & 17.8 & 24.5 & 15.9 & 23.6 \\
\hline Pour point without diluent, K & 300 & 317 & 282 & 276 \\
\hline Pour point with diluent, K & 258 & 263 & 263 & 253 \\
\hline Metals content, mg/kg & \multicolumn{5}{|l|}{} \\
\hline Iron & 21.26 & 291.67 & 7.21 & $<0.8$ \\
\hline Zinc & 1.37 & 42.86 & 1.53 & 0.6 \\
\hline Nickel & 52.94 & 81.42 & 61.78 & 34.1 \\
\hline Vanadium & 112.21 & 180.3 & 140.84 & 52.3 \\
\hline Vanadium/Nickel & 2.12 & 2.21 & 2.78 & 1.53 \\
\hline Chromium & 0.08 & 0.21 & 0.23 & $<1.9$ \\
\hline Calcium & 7.45 & 10.11 & 12.21 & 16.9 \\
\hline Elemental composition of oils, \% & \multicolumn{5}{|l|}{} \\
\hline Carbon & 83.2 & 82.5 & 82.9 & 85.2 \\
\hline Hydrogen & 11.9 & 12.3 & 12.3 & 11.45 \\
\hline Oxygen & 1.0 & 1.1 & 0.9 & 0.55 \\
\hline Nitrogen & 1.1 & 1.2 & 2.9 & 1.10 \\
\hline Sulfur & 2.8 & 2.9 & 3.1 & 1.68 \\
\hline Fractional composition of oils, \% & \multicolumn{5}{|l|}{} \\
\hline Distilled to 473 K, \% & 0.2 & 0.2 & 0.2 & 40 \\
\hline Distilled to 633 K, \% & 21.0 & 22.0 & 21.0 & 68 \\
\hline Distilled to 773 K, \% & 58.0 & 54.0 & 58.0 & - \\
\hline
\end{tabular}

Notes: * viscosity is determined at $323 \mathrm{~K}$; ** indices for oil with diluent

Table 2

Characteristics of gas condensates produced

by Yablunivske and Yarivske GCPD

\begin{tabular}{|l|c|c|}
\hline \multicolumn{1}{|c|}{ Index } & LGC & HGC \\
\hline Fractional composition, $\mathrm{K}$ & 318 & 329 \\
\hline Initial boiling point, $\mathrm{K}$ & 322 & 353 \\
\hline $10 \%$ distilled at, $\mathrm{K}$ & 324 & 365 \\
\hline $20 \%$ distilled at, $\mathrm{K}$ & 327 & 375 \\
\hline $30 \%$ distilled at, $\mathrm{K}$ & 330 & 384 \\
\hline $40 \%$ distilled at, $\mathrm{K}$ & 333 & 395 \\
\hline $50 \%$ distilled at, $\mathrm{K}$ & 339 & 412 \\
\hline $60 \%$ distilled at, $\mathrm{K}$ & 347 & 433 \\
\hline $70 \%$ distilled at, $\mathrm{K}$ & 354 & 483 \\
\hline $80 \%$ distilled at, $\mathrm{K}$ & 366 & 593 \\
\hline $90 \%$ distilled at, $\mathrm{K}$ & $393(99 \%)$ & $623(92 \%)$ \\
\hline End boiling point, $\mathrm{K}$ & 696 & 758 \\
\hline Density, $\mathrm{kg} / \mathrm{m}^{3}$ & 1.4015 & 1.4353 \\
\hline Refractive index $n_{D}{ }^{20}$ & \multicolumn{2}{|c|}{} \\
\hline
\end{tabular}


Characteristics of commercial types of demulsifiers

\begin{tabular}{|c|c|c|c|c|}
\hline \multirow{2}{*}{ Demulsifier } & \multicolumn{4}{|c|}{ Index } \\
\cline { 2 - 5 } & Viscosity at $293 \mathrm{~K}, \mathrm{~mm}^{2} / \mathrm{s}$ & Density, $\mathrm{kg} / \mathrm{m}^{3}$ & Flashing point,K & Solubility \\
\hline PM grade A & 20 & 980 & 299 & water-soluble \\
\hline PM grade B & 30 & 985 & $>373$ & water-soluble \\
\hline PM-1441 grade A & 12 & 935 & 305 & oil-soluble \\
\hline Dissolvan-4411 & 29 & 950 & 284 & water-soluble \\
\hline Dissolvan-2830 & 64 & 940 & 284 & oil-soluble \\
\hline Dissolvan-3359 & 129 & 890 & 301 & oil-soluble \\
\hline Dissolvan-3431 & 30 & 920 & 284 & water-soluble \\
\hline
\end{tabular}

To ensure the production of high-viscosity oil, it is diluted with a stable gas condensate. For the researches we used light gas condensate (LGC) and heavy gas condensate (HGC) produced by Yablunivske and YarivGas Condensate Processing Departments (Ukraine), respectively. Their characteristics are described in Table 2.

The following demulsifiers were used for research. Demulsifiers PM grade A and PM grade B are a mixture of block copolymers of ethylene and propylene oxides dissolved in methanol. Demulsifier PM-1441 grade B is a mixture of block copolymers of ethylene and propylene oxides dissolved in naphta solvent and isobutanol. All mentioned demulsifiers are produced at PJSC Barva Fine Organic Synthesis Plant (Ukraine). Dessolvan demulsifiers are manufactured by Clariant (Switzerland). Dissolvan-3359 is a mixture of crosslinked block copolymers of ethylene and propylene oxides and oxyethylated resins in alcohols and aromatic hydrocarbons; Dissolvan-3431 is a crosslinked block copolymer of ethylene and propylene oxides dissolved in methanol; Dissolvan-2830 is a mixture of non-iogenic surface active substances dissolved in a mixture of methanol and xylene; Dissolvan-4411 is a mixture of block copolymers of ethylene and propylene oxides dissolved in methanol.

The characteristics of commercial types of demulsifiers used for dewatering of heavy oils are represented in Table 3.

\subsection{Method for Determining the Water Content in Emulsions}

Determination of water content in emulsions was performed by the Dean-Stark method. It is a simultaneous distillation of water together with the diluent from oil aliquot. The fraction boiled within $353-393 \mathrm{~K}$ was used as a diluent. The water content in the oil was calculated by the formula:

$$
W=\frac{V \cdot \rho_{d}}{C} \cdot 100 \%
$$

where $W$ is the water content, wt $\%$; $\rho_{d}$ is a density of the dispersed phase, $\mathrm{g} / \mathrm{ml} ; V$ is a volume of water in the trap, $\mathrm{ml} ; C$ is an aliquot of oil under study, $\mathrm{g}$.

\subsection{Procedure of Emulsions Dewatering}

Emulsion $(100 \mathrm{ml})$ is loaded into an extractor equipped with a water jacket. The designed temperature in the extractor is provided by a thermostat. The extractor is equipped with a mechanical stirrer, the speed of which can be adjusted by changing the voltage applied to the motor by means of laboratory transformers.

The samples are kept at a given temperature for $15 \mathrm{~min}$. Then a given amount of demulsifier is added by micropipette and the mixture is stirred for $5 \mathrm{~min}$.

All experiments were performed at elevated temperatures, depending on the experimental conditions. After mixing, the emulsion was left to stand for a specified period of time. The amount of demulsifier added to the emulsion depended on the conditions. The water released during the emulsion settling was separated and the volume was measured. To check the water balance, the residual water content in the emulsion was determined. At least three parallel determinations were performed for each sample of block copolymer and its solution, the arithmetic mean was taken as the true value. In cases of discrepancies in the results obtained by more than 5\%, parallel studies were repeated.

Dewatering of samples with the addition of various demulsifiers was performed at the temperatures of 323 , 333 and $343 \mathrm{~K}$. The amount of demulsifier was $2 \mathrm{ml}$ per $100 \mathrm{ml}$ of oil sample. Demulsifiers were added as a $5 \%$ solution in a suitable solvent (in water if the demulsifier is a water-soluble one and in a solvent if demulsifier is an oil-soluble), the settling time was $4 \mathrm{~h}$. Demulsifiers with the highest degree of dewatering were selected according to the results of the research.

To reduce the oils viscosity and improve the degree of dewatering, light or heavy gas condensate was added to the samples in the amount of $30 \mathrm{wt} \%$. The change in viscosity of the obtained samples was determined depending on the temperature. Sample 4 contained LGC in its composition, which was added at the stage of extraction, so we did not add gas condensate to this sample. Thus 7 products were received. 
Demulsifiers were added to each sample, which showed the highest degree of dewatering in previous studies. The amount of demulsifier solution was $0.2 ; 0.5$; 1 and $2 \mathrm{ml}$ per $100 \mathrm{ml}$ of oil sample. Based on the results obtained from 7 tested demulsifiers the most effective one was selected. Settling time and temperature limits were chosen based on previous studies.

\section{Results and Discussion}

Based on the analysis of the results presented in Table 1, it was found that the first three samples of oil in terms of density and viscosity can be described as heavy oil; sample 4 has some lower density compared to other due to the content of gas condensate in it. The viscosity of oils was determined at 313 and $323 \mathrm{~K}$, because at lower temperatures it is impossible to measure this value. In terms of viscosity, oil is characterized as the highly viscous (exclusion is sample 4 due to dilution by gas condensate at the production stage).

To select the best method for oil dewatering it is important to determine such parameters as coking ability, content of sulfuric acid resins, the pour point of oil, fractional composition, metal content and elemental composition.

Coking ability is a factor affecting the quality of raw materials for further processing which characterizes the tendency of oils to coke formation when heated. Oils have a fairly high rate of coking ability. Distillation data showed that three oil samples are similar in the composition; they contain virtually no gasoline fractions, about $20 \%$ of diesel fractions and more than $40 \%$ of fractions distilled above $773 \mathrm{~K}$. This will complicate the distillation process. For sample 4 about $30 \%$ of diesel fraction is boiled up to $623 \mathrm{~K}$ and $40 \%$ of the diluents is boiled up to $473 \mathrm{~K}$. Regarding the content of carbon, nitrogen and oxygen, all oils are similar, they are characterized by a high sulfur content $(2-3 \%)$. Oils are characterized by a high content of metals, especially vanadium and nickel. There is a lot of iron in sample 2.

Table 4 presents the results of oil dewatering with the addition of oil- and water-soluble demulsifiers at the temperatures of 323,333 and $343 \mathrm{~K}$.

When adding any investigated demulsifiers we do not observe dewatering of heavy oils emulsions at the temperatures of 323 and $333 \mathrm{~K}$; the amount of separated water is $12-13 \%$. Increasing the temperature to $343 \mathrm{~K}$ increases the efficiency of dewatering in some cases up to 20-22\%, but even these results are unsatisfactory. However, the best dewatering results were exhibited by oil-soluble demulsifiers PM-1441 grade A, Dissolvan-2830 and Disolvan-3359, which were selected for further research.

At the next stage of research, $30 \%$ of LGC or HGC were added to oil samples, and the change in viscosity depending on temperature was determined. The results are represented in Figs. 1-3.

Table 4

Dewatering of heavy oils from Yablunivske field with the addition of $5 \%$ solution of demulsifier

\begin{tabular}{|c|c|c|c|c|}
\hline \multirow{2}{*}{ Demulsifier } & \multirow{2}{*}{ Oil sample } & \multicolumn{3}{|c|}{ Amount of settled water at definite temperature, vol \% } \\
\hline & & $323 \mathrm{~K}$ & $333 \mathrm{~K}$ & $343 \mathrm{~K}$ \\
\hline \multirow{3}{*}{ PM grade A } & 1 & 2 & 9 & 18 \\
\hline & 2 & 1 & 6 & 13 \\
\hline & 3 & 3 & 9 & 19 \\
\hline \multirow{3}{*}{ PM grade B } & 1 & 1 & 7 & 14 \\
\hline & 2 & 1 & 5 & 10 \\
\hline & 3 & 2 & 8 & 16 \\
\hline \multirow{3}{*}{ PM-1441 grade A } & 1 & 2 & 10 & 19 \\
\hline & 2 & 2 & 9 & 14 \\
\hline & 3 & 2 & 11 & 20 \\
\hline \multirow{3}{*}{ Dissolvan-4411 } & 1 & 2 & 9 & 17 \\
\hline & 2 & 1 & 7 & 14 \\
\hline & 3 & 4 & 9 & 18 \\
\hline \multirow{3}{*}{ Dissolvan-2830 } & 1 & 2 & 12 & 20 \\
\hline & 2 & 2 & 10 & 14 \\
\hline & 3 & 3 & 12 & 20 \\
\hline \multirow{3}{*}{ Dissolvan-3359 } & 1 & 4 & 13 & 22 \\
\hline & 2 & 3 & 10 & 14 \\
\hline & 3 & 4 & 11 & 24 \\
\hline \multirow{3}{*}{ Dissolvan-3431 } & 1 & 2 & 12 & 21 \\
\hline & 2 & 2 & 9 & 12 \\
\hline & 3 & 2 & 11 & 20 \\
\hline
\end{tabular}

Note: demulsifier amount is $2 \mathrm{ml}$; settling time is $4 \mathrm{~h}$ 


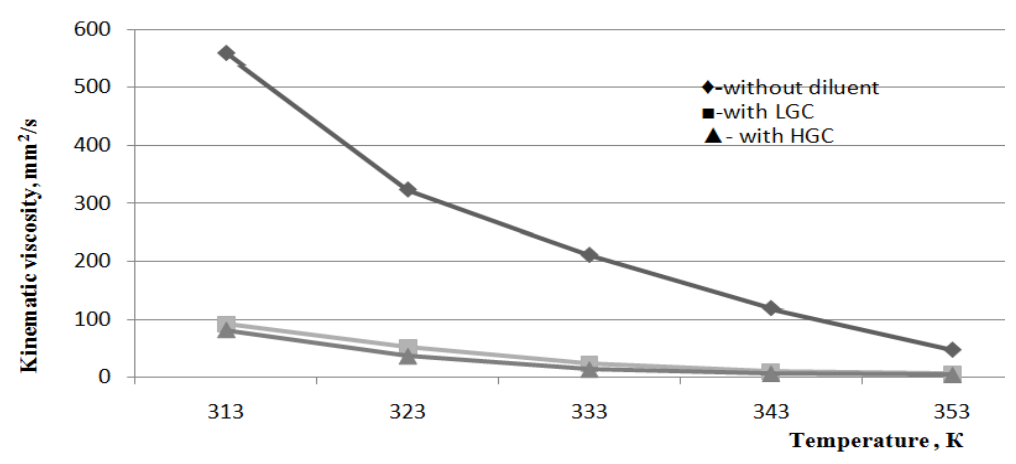

Fig. 1. Change in viscosity of sample 1 depending on temperature

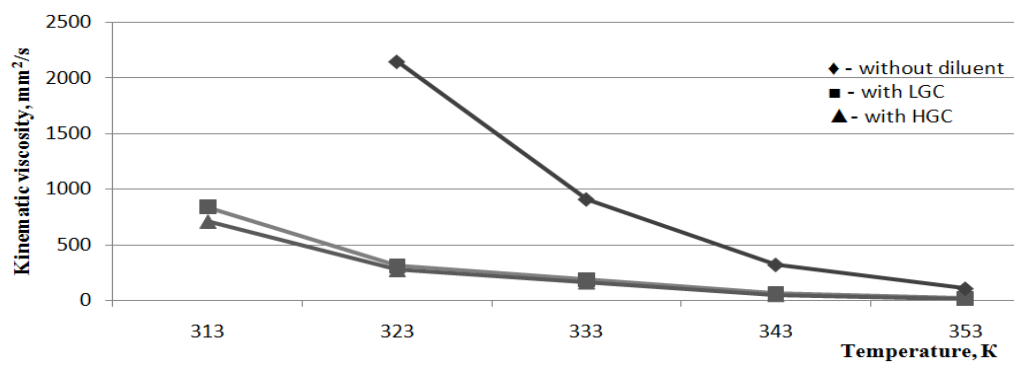

Fig. 2. Change in viscosity of sample 2 depending on temperature

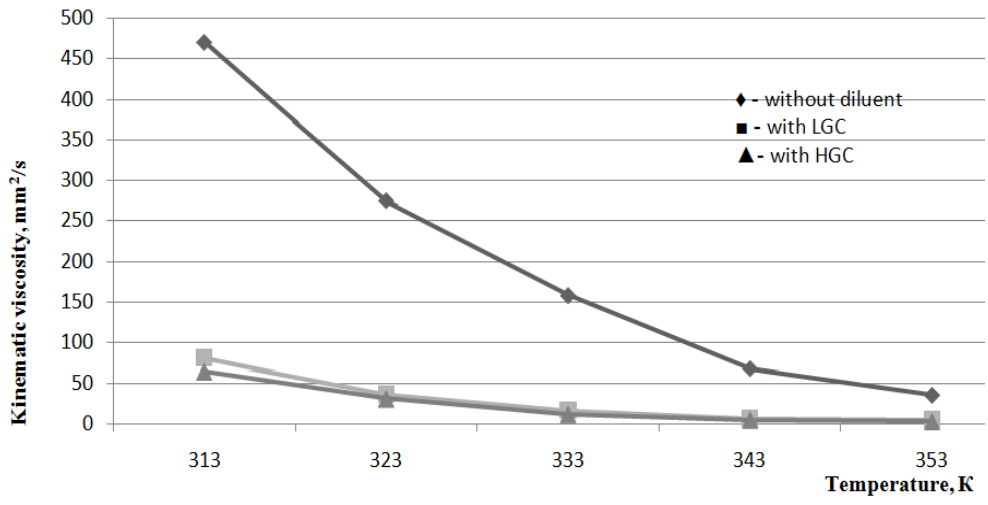

Fig. 3. Change in viscosity of sample 3 depending on temperature

Dilution of the oil samples with LGC and HGC in the amount of $30 \%$ decreases the viscosity by almost 5-6 times. A greater decrease in viscosity is observed when oil is diluted with HGC. However, in the case of dilution with LGC a part of the asphalt-resinous substances is not dissolved, which negatively affects the homogenization of the oil emulsion and contributes to its breaking.

Dewatering of the obtained samples was performed with the addition of demulsifier solution in the amount of $0.2,0.5,1$ and $2 \mathrm{ml}$, the dewatering temperature was $323 \mathrm{~K}$ (Tables 5 and 6).

The results show that adding light or heavy gas condensate significantly improves the dewatering of heavy high-viscosity oils. However, to achieve a significant result, it is necessary to carry out the process at higher temperatu- res. Demulsifiers PM-1441 brand A of domestic production and imported demulsifier Dissolvan-2830 and Dissolvan3359 have approximately the same efficiency. Taking into account the significant difference in price and availability, the demulsifier PM-1441 grade A was chosen to determine the optimal dewatering conditions. Moreover, the selected demulsifier is based on block copolymers of ethylene and propylene oxides (85:15)and have a weight of block copolymer 3500, which increases the diffusion of the demulsifier in oil and aqueous media to the phase boundary and increases its demulsifying ability.

The effect of demulsifier amount and temperature on the dewatering efficiency was investigated. Oil samples with LGC as a diluent were used for investigations. 
Table 5

Influence of demulsifier amount on dewatering of high-viscosity oils in a mixture with $30 \%$ LGC at $323 \mathrm{~K}$

\begin{tabular}{|c|c|c|c|c|c|}
\hline \multirow[t]{2}{*}{ Oil sample } & \multirow{2}{*}{$\begin{array}{l}\text { Water content in } \\
\text { oil, wt } \%\end{array}$} & \multicolumn{4}{|c|}{$\begin{array}{l}\begin{array}{l}\text { Amount of settled water when adding various amounts of } 5 \% \text { demulsifier solution, } \\
\text { vol } \%\end{array} \\
\end{array}$} \\
\hline & & $0.2 \mathrm{ml}$ & $0.5 \mathrm{ml}$ & $1.0 \mathrm{ml}$ & $2.0 \mathrm{ml}$ \\
\hline \multicolumn{6}{|c|}{ PM-1441 grade A } \\
\hline 1 & 5.1 & 32 & 42 & 69 & 86 \\
\hline 2 & 25.2 & 12 & 25 & 53 & 74 \\
\hline 3 & 5.5 & 21 & 39 & 62 & 84 \\
\hline 4 & 5.2 & 51 & 63 & 89 & 95 \\
\hline \multicolumn{6}{|c|}{ Dissolvan-2830 } \\
\hline 1 & 5.1 & 29 & 38 & 67 & 84 \\
\hline 2 & 25.2 & 11 & 24 & 49 & 72 \\
\hline 3 & 5.5 & 20 & 37 & 60 & 79 \\
\hline 4 & 5.2 & 49 & 62 & 87 & 95 \\
\hline \multicolumn{6}{|c|}{ Dissolvan-3359 } \\
\hline 1 & 5.1 & 33 & 43 & 70 & 91 \\
\hline 2 & 25.2 & 14 & 29 & 56 & 81 \\
\hline 3 & 5.5 & 23 & 41 & 64 & 89 \\
\hline 4 & 5.2 & 53 & 69 & 93 & 94 \\
\hline
\end{tabular}

Table 6

Influence of demulsifier amount on dewatering of high-viscosity oils in a mixture with $30 \%$ HGC at $323 \mathrm{~K}$

\begin{tabular}{|c|c|c|c|c|c|}
\hline \multirow[t]{2}{*}{ Oil sample } & \multirow{2}{*}{$\begin{array}{l}\text { Water content in } \\
\text { oil, wt } \%\end{array}$} & \multicolumn{4}{|c|}{$\begin{array}{l}\text { Amount of settled water when adding various amounts of } 5 \% \text { demulsifier solution, } \\
\text { vol } \%\end{array}$} \\
\hline & & $0.2 \mathrm{ml}$ & $0.5 \mathrm{ml}$ & $1.0 \mathrm{ml}$ & $2.0 \mathrm{ml}$ \\
\hline \multicolumn{6}{|c|}{ PM-1441 grade A } \\
\hline 1 & 5.1 & 35 & 45 & 73 & 94 \\
\hline 2 & 25.2 & 16 & 32 & 59 & 84 \\
\hline 3 & 5.5 & 25 & 44 & 69 & 93 \\
\hline \multicolumn{6}{|c|}{ Dissolvan-2830 } \\
\hline 1 & 5.1 & 34 & 44 & 72 & 92 \\
\hline 2 & 25.2 & 15 & 33 & 61 & 85 \\
\hline 3 & 5.5 & 26 & 45 & 68 & 92 \\
\hline \multicolumn{6}{|c|}{ Dissolvan-3359 } \\
\hline 1 & 5.1 & 35 & 45 & 74 & 94 \\
\hline 2 & 25.2 & 16 & 35 & 63 & 87 \\
\hline 3 & 5.5 & 27 & 47 & 70 & 95 \\
\hline
\end{tabular}

Table 7

Effect of temperature and PM-1441 amount on dewatering efficiency

\begin{tabular}{|c|c|c|c|c|c|}
\hline \multirow[t]{2}{*}{ Temperature, K } & \multirow[t]{2}{*}{ Oil sample } & \multirow{2}{*}{$\begin{array}{l}\text { Water content in } \\
\text { oil, wt } \%\end{array}$} & \multicolumn{3}{|c|}{$\begin{array}{l}\text { Amount of settled water when adding various amounts of } \\
5 \% \text { demulsifier solution, vol \% }\end{array}$} \\
\hline & & & $0.2 \mathrm{ml}$ & $0.5 \mathrm{ml}$ & $1 \mathrm{ml}$ \\
\hline \multirow{4}{*}{323} & 1 & 5.1 & 32 & 42 & 69 \\
\hline & 2 & 25.2 & 12 & 25 & 53 \\
\hline & 3 & 5.5 & 21 & 39 & 62 \\
\hline & 4 & 15.2 & 51 & 63 & 89 \\
\hline \multirow{4}{*}{333} & 1 & 5.1 & 49 & 63 & 91 \\
\hline & 2 & 25.2 & 27 & 42 & 79 \\
\hline & 3 & 5.5 & 43 & 59 & 89 \\
\hline & 4 & 15.2 & 74 & 92 & 93 \\
\hline \multirow{4}{*}{343} & 1 & 5.1 & 69 & 86 & 95 \\
\hline & 2 & 25.2 & 39 & 59 & 87 \\
\hline & 3 & 5.5 & 65 & 81 & 90 \\
\hline & 4 & 15.2 & 85 & 94 & 95 \\
\hline
\end{tabular}


The values of the viscosity and water content of the investigated samples are different, so the optimal dewatering conditions will be also different. For the samples 1, 3 and 4 the optimal temperature is $333-343 \mathrm{~K}$ and the demulsifier amount is $0.2-0.5 \mathrm{ml}$. For sample 2, (with the highest viscosity), the dewatering temperature should be at least $343 \mathrm{~K}$ and demulsifier amount should be no less than $1 \mathrm{ml}(500 \mathrm{ppm})$.

\section{Conclusions}

Thus, to intensify the processes of dewatering and desalting of water-oil emulsions of heavy high-viscosity oils of the eastern region of Ukraine, it is necessary to add a diluent to reduce their viscosity and select an effective demulsifier that can destroy water shells. To reduce the viscosity of oil from Yablunivske field and to improve the dewatering process, it is advisable to dilute oil with heavy gas condensate in the amount of $30 \%$. The addition of light gas condensate has a lesser effect on the viscosity of the emulsion, because LGC dissolves less resinous and asphaltene substances and their precipitation occurs. For highly effective dewatering of water-oil emulsions of heavy high-viscosity oils of the eastern region of Ukraine it is expedient to add domestic demulsifier of PM-1441 grade A, produced on the basis of block copolymers of ethylene and propylene oxides in the amount of $0.2-$ $0.5 \mathrm{ml}$ or $0.5-1.0 \mathrm{ml}$. The dewatering temperature was found to be $333-343 \mathrm{~K}$, for heavier oil it should be more than $343 \mathrm{~K}$. The dewatering degree is about 95 and $87 \%$, respectively.

\section{References}

[1] Gounder R.: Introductory Chapter: Heavy Crude Oil ProcessingAn Overview [in:] Gounder R. (Ed.), Processing of Heavy Crude Oils. Challenges and Opportunities.

https://doi.org/10.5772/intechopen.90425

[2] Etherington J., McDonald I.: SPE Annual Technical Conference and Exhibition. USA, Houston 2004. https://doi.org/10.2118/90242MS

[3] Vitvitsky Ya., Pilka M.: Nauk. Visnyk Ivano-Frankivsk Nats. Techn. Univ., 2016,1, 30.

[4] Ekott E., Akpabio E.: J. Eng. Appl. Sci., 2011, 6, 200. https://doi.org/10.3923/jeasci.2011.200.204

[5] McLean J., Kilpatrick P.: J. Colloid Interf. Sci., 1997, 189, 242. https://doi.org/10.1006/jcis.1997.4807

[6] Ermakov S., Mordvinov A.: Neftegazovoe Delo, 2007.

http://ogbus.ru/files/ogbus/authors/Ermakov/Ermakov_1.pdf

[7] https://core.ac.uk/download/pdf/38636262.pdf

[8] Orea M., Mujica Y., Diaz A. et al.: Heavy Oil Latin American

Conference (HOLA 2015), Bogotá Colombia 2015.

https://www.researchgate.net/publication/286937181

[9] Gateau P., Hénaut I., Barré L.,Argillier J.: Oil Gas Sci. Technol., 2004, 59, 503. https://doi.org/10.2516/ogst:2004035
[10] Topilnytskyy P., Romanchuk V., Yarmola T., Stebelska H.: Chem. Chem. Technol., 2020, 14, 412.

https://doi.org/10.23939/chcht14.03.412

[11] Romanchuk V., Topilnytskyy P.: Chem. Chem. Technol., 2010, 4, 231.

[12] Netipa V., Lytvyn B.: Naftogazova Galuz Ukrainy, 2015, 4, 39.

[13] Gajek A., Zakroczymski T., Topilnytsky P., Romanchuk V.:

Chem. Chem. Technol., 2012, 6, 209.

https://doi.org/10.23939/chcht06.02.209

[14] Ahmad M., Samsuri S., Amran N.: Methods for Enhancing Recovery of Heavy Crude Oil [in:] Gounder R. (Ed.): Processing of Heavy Crude Oils. Challenges and Opportunities.

https://doi.org/10.5772/intechopen.90326

[15] Xu X., Yang J., Zhang B., Gao J.: Petrol.Sci. Technol., 2007, 25, 1375. https://doi.org/10.1080/10916460600803694

[16] Warren K.: SPE International Thermal Operations and Heavy Oil Symposium and International Horizontal Well Technology

Conference, Canada, Calgary2002. https://doi.org/10.2118/78944MS

[17] Kumar S., Rajput V., MahtoV.: SPE Prod \&Oper 1-12, 2020. https://doi.org/10.2118/204452-PA

[18] Raya S., Saai I., Ahmed A., Umar A.: J. Pet. Explor.

Prod.Technol., 2020, 10, 1711. https://doi.org/10.1007/s13202-02000830-7

[19] Fang C., Chang B., Lai P., Klaila W.: Chem. Eng. Commun., 1988, 73, 227. https://doi.org/10.1080/00986448808940444

[20] Binner E., Robinson J., Silvester S., Lester E.: Fuel, 2014, 116, 516. https://doi.org/10.1016/j.fuel.2013.08.042

[21] Wu J., Wei W., Li S. et al.: J. Membr. Sci., 2018, 563, 126. https://doi.org/10.1016/j.memsci.2018.05.065

[22] Wang Z., Gu S., Zhou L.: Ultrason.Sonochem., 2018, 40, 1014. https://doi.org/10.1016/j.ultsonch.2017.08.037

[23] Yi M., Huang J., Wang L.: J. Chem., 2017, 2017.

https://doi.org/10.1155/2017/9147926

[24] Amani M., Idris M.: J. Petrol. Environ. Biotechnol., 2017, 8,

330. https://doi.org/10.4172/2157-7463.1000330

[25] da Silva E., Santos D., de Brito M. et al.: Fuel, 2014, 128, 141. https://doi.org/10.1016/j.fuel.2014.02.076

[26] Abed S., Abdurahman N., Yunus R. et al.: IOP Conf. Ser.

Mater. Sci. Eng., 2019, 702, 012060. https://doi.org/10.1088/1757899X/702/1/012060

[27] Balsamo M., Erto A., Lancia A.: Braz. J. Chem. Eng., $2017,34$. https://doi.org/10.1590/0104-6632.20170341s20150583

[28] Silva E., Santos D., Alves D. et al.: Energy Fuels, 2013, 27, 6311.https://doi.org/10.1021/ef302008d

[29] Flores C., Flores E., Hernández E. et al.: J. Mol. Liq., 2014, 196, 249. https://doi.org/10.1016/j.molliq.2014.03.044

[30] https://cyberleninka.ru/article/n/kompozitsionnyy-deemulgatordlya-podgotovki-tyazhelyh-vysokovyazkih-neftey/viewer

[31] Al-Sabagh A., Elsharaky E., El-Tabey A.: J. Dispers. Sci.

Technol., 2017, 38, 288.

https://doi.org/10.1080/01932691.2016.1163720

[32] Topilnytskyy P., Romanchuk V., Boichenko S., Golych Y.:

Chem. Chem. Technol., 2014, 8, 211.

https://doi.org/10.23939/chcht08.02.211

[33] Nguyen D., Sadeghi N.: International Symposium on Oil Field Chemistry. USA, The Woodlands 2011.

https://doi.org/10.2118/140860-MS

[34] Levchenko D., Bronshtein N., Khudiakova A., Nikolaeva N.:

Emulsii Nefti s Vodoi i Sposoby ikh Razrushenia. Khimia, Moskva 1967. 
[35] Adilbekova A., Omarova K., Karakulova A., Musabekov K.: Colloids Surf. A Physicochem. Eng. Asp., 2015, 480, 433. https://doi.org/10.1016/j.colsurfa.2014.11.004

[36] Rondón M., Pereira J., Bouriat P. et al.: Energy Fuels, 2008, 22, 702. https://doi.org/10.1021/ef7003877

[37] Narro G., Vázquez C., González M.: Petrol. Sci. Technol., 2019, 37, 1347.

[38] Salam K., Alade A.,Arinkoola A.,Opawale A.: J. Petrol.Eng., 2013, 2013. https://doi.org/10.1155/2013/793101

[39] Topilnytskyy P., Paiuk S., Stebelska H. et al.: Chem. Chem. Technol., 2019, 13, 503. https://doi.org/10.23939/chcht13.04.503

Received: December 12, 2020 / Revised: December 15, 2020 / Accepted: January 30, 2021
ОСОБЛИВОСТІ ТЕХНОЛОГЇ̈ ЗНЕВОДНЕННЯ

ВАЖКИХ ВИСОКОВ'ЯЗКИХ НАФТ СХІДНОГО РЕГІОНУ УКРАЇНИ

Анотація. Досліджено високов'язкі нафти Яблунівського родовища (Україна, Полтавська обл). Нафти розбавляли газовим конденсатом для зменшення в'язкості, потім деемульгували різними деемульгаторами. Встановлено, що нафти дочільно розбавляти важским газовим конденсатом, зневоднювати нейоногенним деемульгатором ПМ-1441 марки А на основі блоккополімерів оксидів етилену та пропілену. Ступінь зневоднення при цььому сягає $95 \%$.

Ключові слова: важкка нафта, зневоднення, деемульгування, деемульгатор. 